\title{
Micro-tubular Flame-assisted Fuel Cell Stacks
}

\author{
Ryan J. Milcarek $^{\mathrm{a},{ }^{*}}$, Michael J. Garrett ${ }^{\mathrm{a}}$, Jeongmin Ahn ${ }^{\mathrm{a}}$
}

\begin{abstract}
Similar to the original direct flame fuel cell the flame-assisted fuel cell, which has a solid oxide fuel cell (SOFC) operating in combustion exhaust, can potentially simplify the fuel cell system and has applications in micro-Combined Heat and Power. Development and testing of a 9 microtubular flame-assisted fuel cell stack is demonstrated in this work. Two different systems are investigated having 1) fixed fuel flow rate and varying air flow rate and 2) fixed total flow rate of air and fuel for the micro-Combined Heat and Power burners. The micro-tubular flame-assisted fuel cell stack achieves a significant performance of $237 \mathrm{~mW} \mathrm{~cm}^{-2}$ in model methane combustion exhaust at $0.5 \mathrm{~V}$ and $790^{\circ} \mathrm{C}$ with a lanthanum strontium manganite based cathode.

Electrochemical impedance spectroscopy reveals that the fuel cell ohmic losses are unaltered by variations in the exhaust species concentrations while the polarization losses increase with decreasing first-stage combustion fuel-air equivalence ratio. Variations in the combustion exhaust temperature effects both the ohmic and polarization losses.

Keywords: Flame-assisted fuel cell; Micro-tubular solid oxide fuel cell; Solid-oxide fuel cell (SOFC); Fuel cell stack; Micro-combined heat and power; Fuel-rich combustion
\end{abstract}




\section{INTRODUCTION}

Solid Oxide Fuel Cell (SOFC) systems have been investigated and developed for a range of applications including large scale Combined Heat and Power (CHP) or cogeneration as well as for small scale power generation for the residential sector called micro-CHP [1,2]. SOFC stacks are the key component of this power generation system, boasting high efficiency, moderate to high fuel flexibility and high operating temperatures compared to some of the alternative microCHP devices [3-5]. The SOFC stack is supported by a range of other components making up the thermal management, power electronics and fuel delivery/processing subsystems [6-9]. These systems are complex with much of the internal heat recovery used for fuel and oxidant preheating and fuel reforming.

Direct Flame Fuel Cells (DFFCs) were proposed to overcome some of the system complexities and have been investigated extensively recently [10-23]. DFFCs combine a SOFC with an open flame for power generation. The SOFC itself is unaltered, but the overall system is simplified as the fuel reforming and thermal management for fuel and oxidant preheating are essentially combined [22]. The combustion process reforms fuel into $\mathrm{H}_{2}$ and $\mathrm{CO}$ for SOFC electrochemical power generation while the heat of combustion brings the fuel cell to operating temperature. This allows for many of the advantages reported in DFFC research including less stringent sealing requirements, rapid thermal cycling and high fuel flexibility [10-13].

Recent development in DFFC research led to the Flame-assisted Fuel Cell (FFC) concept in which a 2-stage combustion process is utilized [24]. In this setup a first stage, fuel-rich combustion, generates syngas for electrochemical power generation in the SOFC. The combustion exhaust passes to the fuel cells for power generation and any remaining fuel in the exhaust is combusted in a second stage, fuel-lean combustion. Many of the systems advantages 
for FFCs remain because the combustion process provides fuel reforming and heat generation for the SOFC operation. The second stage fuel-lean combustion provides heat generation, which only needs to be extracted from a single point in the system unlike the more traditional SOFC systems, which have heat extraction from several points [7] for fuel reforming and fuel and oxidant preheating. This allows for simplified design and potentially greater thermal energy recovery and thermal efficiency. In addition, FFCs achieve high fuel utilization compared to DFFCs, which allows for greater electrical efficiencies [24]. These advantages may allow FFC based micro-CHP systems to have reasonable electrical efficiency and high overall system efficiencies compared to traditional SOFC micro-CHP systems.

A single micro-tubular FFC (mT-FFC) operating in model methane combustion exhaust was recently demonstrated $[24,25]$. While the performance achieved for a single cell was promising $\left(430 \mathrm{~mW} \mathrm{~cm}^{-2}\right)$ the performance of a mT-FFC stack needs to be investigated to better understand stack and potential system performance for mT-FFCs. Micro-tubular SOFCs (mTSOFCs) and stacks have been investigated extensively [26-38]. Among the many advantages that the mT-SOFC geometry offers, advantages include secure sealing, rapid startup, rapid thermal cycling, good mechanical strength and high thermal shock resistance [26,30]. These advantages are particularly advantageous for FFC based micro-CHP systems as the combustion based reforming and heating favor these same advantages. Further work is needed on impedance characterization of SOFCs in combustion exhaust. An impedance investigation was conducted for a long term DFFC test [39], but little other work exists to understand how SOFC impedance changes in different combustion environments.

The present work investigates a 9 cell mT-FFC stack performance and impedance in different combustion exhaust conditions. Combustion exhaust compositions for the fuel cell are 
varied by changing the fuel-air equivalence ratio of the first stage methane/air combustion. Two different scenarios were studied to represent a micro-CHP system having 1) fixed fuel flow rate, fixed stack geometry and varying oxidant flow rate to vary the equivalence ratio; 2) varying fuel and oxidant flow rates to vary the equivalence ratio with a fixed stack geometry and fixed total flow rate of fuel and oxidant.

\section{EXPERIMENTAL}

\subsection{Combustion Characterization}

Methane combustion in air under fuel-rich conditions can result in significant generation of $\mathrm{H}_{2}, \mathrm{CO}, \mathrm{CO}_{2}, \mathrm{H}_{2} \mathrm{O}$ and $\mathrm{N}_{2}$. Characterization of dry methane combustion exhaust was reported in the author's previous work and will not be repeated here [24,25]. While characterization of the combustion occurred from fuel-air equivalence ratios of 0.8 to 1.4, equivalence ratios below 1.2 had $\mathrm{H}_{2}$ and $\mathrm{CO}$ volume percentages which were both below 3.3\%. While some electrical power can be generated in these conditions, only the stack performance results for equivalence ratios of 1.2 to 1.4 are reported herein.

\subsection{Fuel Cell Fabrication and Stack Design}

Anode-supported SOFCs were prepared by extruding NiO + YSZ (6:4 w/w, J.T. Baker) anode material with a ram extruder. After extrusion, the anode was dried for $24 \mathrm{~h}$ and then sintered at $1000^{\circ} \mathrm{C}$ for $2 \mathrm{~h}$. Yttria-stabilized zirconia (YSZ, Tosoh) slurry was prepared for dipcoating of the electrolyte layer. During dip coating, both ends of the anode tube were capped leaving bare anode exposed on both sides of the electrolyte coating. The electrolyte was dried for $24 \mathrm{~h}$ prior to sintering to $1400^{\circ} \mathrm{C}$ in air for $4 \mathrm{~h}$. The sintered anode had an internal diameter of 2.4 $\mathrm{mm}$ and outer diameter of $3.2 \mathrm{~mm}$. The electrolyte is $16 \mu \mathrm{m}$ thick. $\left(\mathrm{La}_{0.8} \mathrm{Sr}_{0.2}\right)_{0.95} \mathrm{MnO}_{3-\mathrm{x}}(\mathrm{LSM})+$ YSZ (Fuel Cell Materials, 50:50 w/w) cathode slurry was applied via dip-coating. A similar 
procedure of capping the tube ends occurred, but with both the exposed anode and a portion of the electrolyte covered to prevent direct contact of the cathode with the anode. The cathode layer was dried for $24 \mathrm{~h}$ and sintered at $1100^{\circ} \mathrm{C}$ for $2 \mathrm{~h}$. Each individual cell in the 9 cell stack had an active area of $1.67 \mathrm{~cm}^{2}$ for a total stack area of $15.03 \mathrm{~cm}^{2}$. After sintering, gold precious metal paste (Fuel Cell Materials) was applied on the exterior of one end of the bare anode tube and fired to $1000^{\circ} \mathrm{C}$ for $2 \mathrm{~h}$. The fired gold is dense, preventing any fuel on the tube interior from leaking. The $9 \mathrm{mT}-\mathrm{SOFCs}$ were connected in series. The 4-probe technique was used with two wires connected to the cathode of cell 1 and two wires connected to the anode of cell 9. Anode current was collected via the gold applied on the tube exterior. Silver paste was applied to the cathode for current collection. The mT-SOFC fuel inlets were sealed to steel tubing using ceramic adhesive, which covered and sealed the remaining bare anode. A schematic of the stack is shown in the supplementary material. The $9 \mathrm{mT}-\mathrm{SOFCs}$ were arranged in a circle with the steel tubing fed through an alumina block to hold the steel tubing in place. The exhaust side is not sealed which simplifies the design and allows for the second stage, fuel-lean combustion. This design eliminates all wires on the tube interior preventing wire exposure at the tubes exhaust side where combustion occurs.

\subsection{Fuel Cell Stack Testing}

The mT-FFC stack electrochemical performance was characterized using the currentvoltage (I-V) method with the 4-probe technique. A Keithley 2420 sourcemeter interfaced with a computer collects the stack performance characteristics including open circuit voltage (OCV), power density and polarization. A K-type thermocouple was placed in the center of the 9 cell stack to monitor the temperature during testing. The flow rate of $\mathrm{H}_{2}, \mathrm{CO}, \mathrm{CO}_{2}$, and $\mathrm{N}_{2}$ were regulated using mass flow controllers (MFCs). The flow rates were calculated by multiplying the 
volume $\%$ of each species measured in the gas chromatograph by the total exhaust flow rate $[24,25]$. Other hydrocarbons detected in the exhaust were $<1 \%$ and are not included in the model exhaust. The MFCs were controlled using LabView software. One-way valves were placed downstream of the $\mathrm{H}_{2}$ and $\mathrm{CO}$ MFCs to prevent flashback. The four separate gases are mixed and fed through a common tube to a 9 port manifold that separates the mixture into 9 streams. Flow orifices downstream of the manifold regulate the flow through each tube. An array of 9 pressure transducers monitors the pressure drop between the pressure transducer and the tube outlet. The pressure drop across each cell was monitored using LabView data acquisition to ensure that each of the 9 cells had comparable pressure drop and flow. The mT-FFC stack was placed in a tubular furnace and heated to $800^{\circ} \mathrm{C}$ at a rate of $5^{\circ} \mathrm{C}$ per minute. The testing setup is shown in the supplementary material.

The actual flow rates used for the 9 cell stack were determined for two different scenarios of the residential furnace system described previously [24]. Residential furnaces can be designed to operate at a constant flow rate of fuel into the burner. If the fuel flow rate of the burner is fixed then the air flow rate varies to achieve the appropriate equivalence ratio. As a result, the total flow rate of combustion exhaust varies, but the fuel cell stack area remains the same. To study these conditions, the flow rates shown in Table 1 were computed to simulate a furnace having a fixed flow rate of fuel, constant stack area, and a varying air flow rate in order to achieve the appropriate equivalence ratios. The first stage combustion equivalence ratios are shown along with the theoretical fuel cell voltage for the combustion exhaust composition. 
Table 1: Flow rate of each component gas in the model methane combustion exhaust with a fixed fuel flow rate into the furnace and theoretical fuel cell voltage for the composition at $790^{\circ} \mathrm{C}$ and atmospheric pressure.

\begin{tabular}{ccccccc}
\hline $\begin{array}{c}\text { Equivalence } \\
\text { Ratio }\end{array}$ & $\begin{array}{c}\mathrm{H}_{2} \\
\left(\mathrm{~mL} \mathrm{~min}^{-1}\right)\end{array}$ & $\begin{array}{c}\mathrm{CO} \\
\left(\mathrm{mL} \mathrm{min}^{-1}\right)\end{array}$ & $\begin{array}{c}\mathrm{CO}_{2} \\
\left(\mathrm{~mL} \mathrm{~min}^{-1}\right)\end{array}$ & $\begin{array}{c}\mathrm{N}_{2} \\
\left(\mathrm{~mL} \mathrm{~min}^{-1}\right)\end{array}$ & $\begin{array}{c}\text { Total } \\
\left(\mathrm{mL} \mathrm{min}^{-1}\right)\end{array}$ & $\begin{array}{c}\text { Fuel Cell } \\
\text { Voltage }(\mathrm{V})\end{array}$ \\
\hline 1.20 & 95.5 & 102.6 & 221.8 & $1,804.1$ & $2,224.0$ & 0.906 \\
1.25 & 136.8 & 119.5 & 197.2 & $1,690.8$ & $2,144.3$ & 0.917 \\
1.30 & 166.1 & 134.3 & 176.8 & $1,594.9$ & $2,072.1$ & 0.925 \\
1.35 & 231.1 & 161.0 & 165.8 & $1,447.0$ & $2,004.9$ & 0.937 \\
1.40 & 241.5 & 169.7 & 147.2 & $1,384.2$ & $1,942.6$ & 0.941 \\
\hline
\end{tabular}

A second scenario was studied in which the total flow rate of exhaust remains unchanged for each equivalence ratio. Achieving this situation in practice would require adjustments in the flow rate of both air and fuel into the furnace. For a total exhaust flow rate of $1800 \mathrm{~mL} \mathrm{~min}^{-1}$ (a flow rate of $200 \mathrm{~mL} \mathrm{~min}^{-1}$ per cell) the flow rates shown in Table 2 were utilized.

Table 2: Flow rate of each component gas in the model methane combustion exhaust with the total exhaust flow rate fixed and theoretical fuel cell voltage for the composition at $790^{\circ} \mathrm{C}$ and atmospheric pressure.

\begin{tabular}{ccccccc}
\hline $\begin{array}{c}\text { Equivalence } \\
\text { Ratio }\end{array}$ & $\begin{array}{c}\mathrm{H}_{2} \\
\left(\mathrm{~mL} \mathrm{~min}^{-1}\right)\end{array}$ & $\begin{array}{c}\mathrm{CO} \\
\left(\mathrm{mL} \mathrm{min}^{-1}\right)\end{array}$ & $\begin{array}{c}\mathrm{CO}_{2} \\
\left(\mathrm{~mL} \mathrm{~min}^{-1}\right)\end{array}$ & $\begin{array}{c}\mathrm{N}_{2} \\
\left(\mathrm{~mL} \mathrm{~min}^{-1}\right)\end{array}$ & $\begin{array}{c}\text { Total } \\
\left(\mathrm{mL} \mathrm{min}^{-1}\right)\end{array}$ & $\begin{array}{c}\text { Fuel Cell } \\
\text { Voltage }(\mathrm{V})\end{array}$ \\
\hline 1.20 & 77.3 & 83.0 & 179.5 & $1,460.1$ & 1,800 & 0.906 \\
1.25 & 114.8 & 100.3 & 165.6 & $1,419.3$ & 1,800 & 0.917 \\
1.30 & 144.3 & 116.7 & 153.6 & $1,385.5$ & 1,800 & 0.925 \\
1.35 & 207.5 & 144.5 & 148.9 & $1,299.1$ & 1,800 & 0.937 \\
1.40 & 223.7 & 157.2 & 136.4 & $1,282.6$ & 1,800 & 0.941 \\
\hline
\end{tabular}

\section{RESULTS AND DISCUSSION}

In order to establish a baseline for the fuel cell stack performance, the $9 \mathrm{mT}$-SOFC stack was first tested in $\mathrm{H}_{2}$ fuel to characterize the fuel cells performance. Three separate tests were 
conducted with total $\mathrm{H}_{2}$ flow rates of 200,250 and $300 \mathrm{~mL} \mathrm{~min}^{-1}$. The stack temperature measured was $790^{\circ} \mathrm{C}$. The OCV for the 9 mT-SOFC stack was $9.7,9.78$ and $9.83 \mathrm{~V}$ at a $\mathrm{H}_{2}$ flow rate of 200, 250 and $300 \mathrm{~mL} \mathrm{~min}^{-1}$, respectively. This results in an average OCV of $1.078 \mathrm{~V}$, 1.087 V and $1.092 \mathrm{~V}$ per cell for these conditions. Fig. 1 shows the results of the stack testing. The 9 cell mT-SOFC stack achieved a peak power of 4.78, 5.01 and 5.05 $\mathrm{W}$ at a $\mathrm{H}_{2}$ flow rate of 200, 250 and $300 \mathrm{~mL} \mathrm{~min}^{-1}$, respectively. This corresponds to peak power densities of 320, 335 and $337 \mathrm{~mW} \mathrm{~cm}^{-2}$. At a flow rate of $200 \mathrm{~mL} \mathrm{~min}^{-1}$ of $\mathrm{H}_{2}$ the peak power density occurs at a fuel utilization of $41.9 \%$. The fuel utilization at the peak power density decreased at higher $\mathrm{H}_{2}$ flow rates.
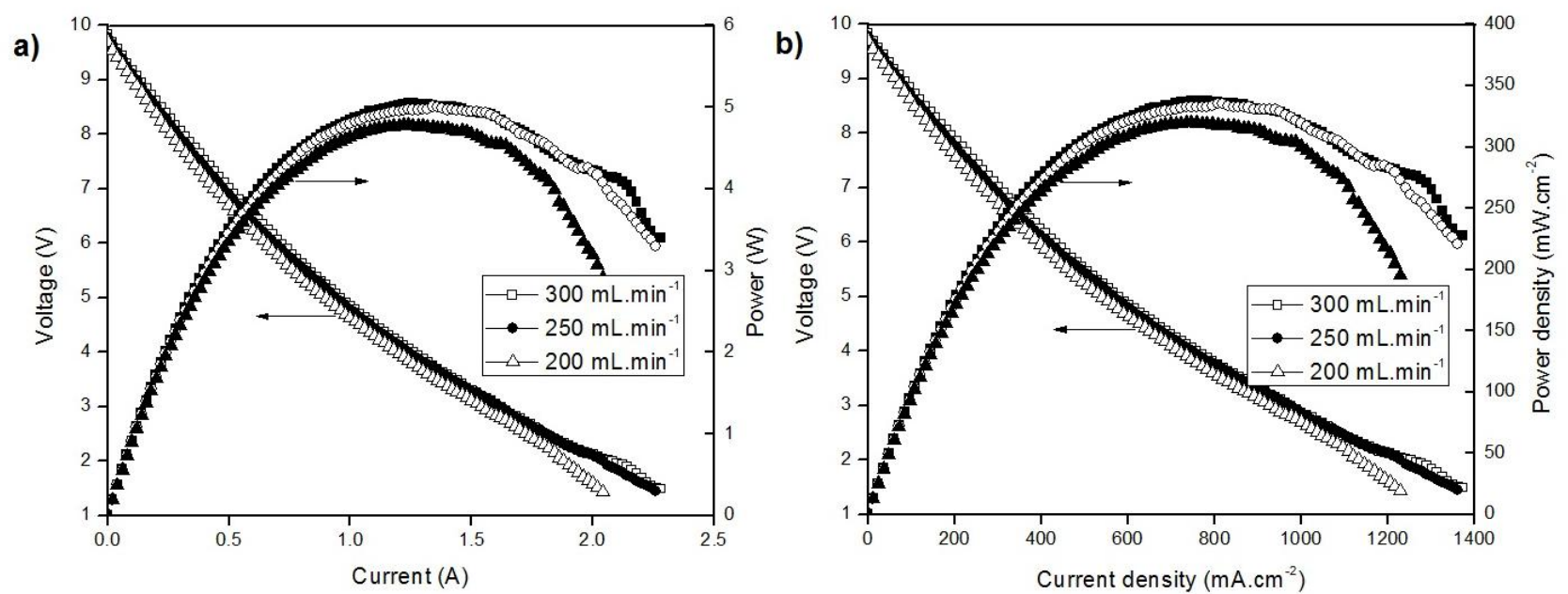

Figure 1: 9 mT-SOFC stack with varying flow rates of $\mathrm{H}_{2}$ operating at $790^{\circ} \mathrm{C}$ showing a) the total power and current and b) the power density and current density.

After establishing the stacks performance with pure $\mathrm{H}_{2}$ fuel, the performance was assessed with the model methane combustion exhaust. Fig. 2 shows the mT-FFC stack performance at a fuel-rich combustion equivalence ratio of $1.2,1.25,1.3,1.35$ and 1.4 with the flow rates for each exhaust species shown in Table 1. These conditions represent a fixed fuel flow rate for the FFC micro-CHP system with the air flow rate adjusting to achieve the desired 
equivalence ratio. The OCV for the mT-FFC stack was $9.05,8.98,8.88,8.83$ and $8.66 \mathrm{~V}$ for combustion equivalence ratios of $1.4,1.35,1.3,1.25$ and 1.2 , respectively. These conditions resulted in peak power densities of $175.7,169.0,154.7,139.7$ and $113.0 \mathrm{~mW} \mathrm{~cm}^{-2}$ for the same equivalence ratios. For the exhaust at a combustion equivalence ratio of 1.4, the peak power density occurred at a $\mathrm{H}_{2}$ and $\mathrm{CO}$ fuel utilization of $11.3 \%$. While this fuel utilization is not high, significant improvements are possible as the stack only achieved a fuel utilization of $41.9 \%$ with pure $\mathrm{H}_{2}$. Furthermore, adjustments in the flow rates were also shown to effect the fuel utilization in the case of the stack with $\mathrm{H}_{2}$ and have been shown to increase the fuel utilization of the mTFFC by almost a factor of 3 [40]. Adjustments in the flow rate and mT-SOFC micro structure are expected to improve the fuel utilization for the stack and result in much higher electrical efficiencies $[24,40]$.

a)

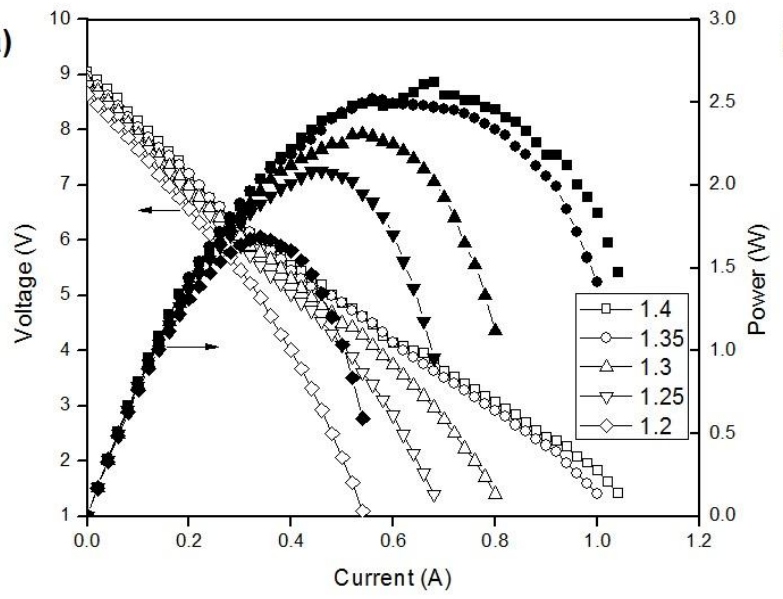

b)

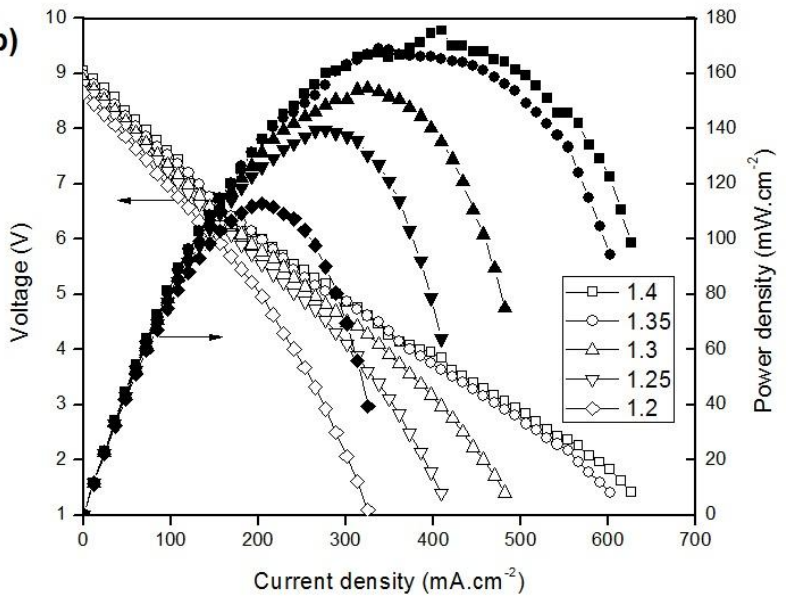

Figure 2: $9 \mathrm{mT}-\mathrm{FFC}$ stack operating at $790^{\circ} \mathrm{C}$ in model methane combustion exhaust at equivalence ratios from 1.2 to 1.4 with Table 1 flow rates; a) the total power and current and b) the power density and current density.

Fig. 3 shows the results of the mT-FFC stack tested under the conditions given in Table $\mathbf{2}$ at a temperature of $790^{\circ} \mathrm{C}$. The flow rates given in Table 2 represent the furnace operating at a 
fixed total flow rate of exhaust and the fuel and air flow rates varying to achieve the required equivalence ratio. As shown, the mT-FFC stack had an OCV of 9.01, 8.99, 8.86, 8.75, and 8.60 $\mathrm{V}$ at combustion equivalence ratios of $1.4,1.35,1.3,1.25$ and 1.2. The peak power for the stack was $3.68,3.67,3.60,3.40$, and $2.88 \mathrm{~W}$ for the same equivalence ratios, respectively. This corresponds to an average power density of 246, 245, 241, 228 and $193 \mathrm{~mW} \mathrm{~cm}^{-2}$, respectively. The stack performance is compared to other stack results in Table 3 .
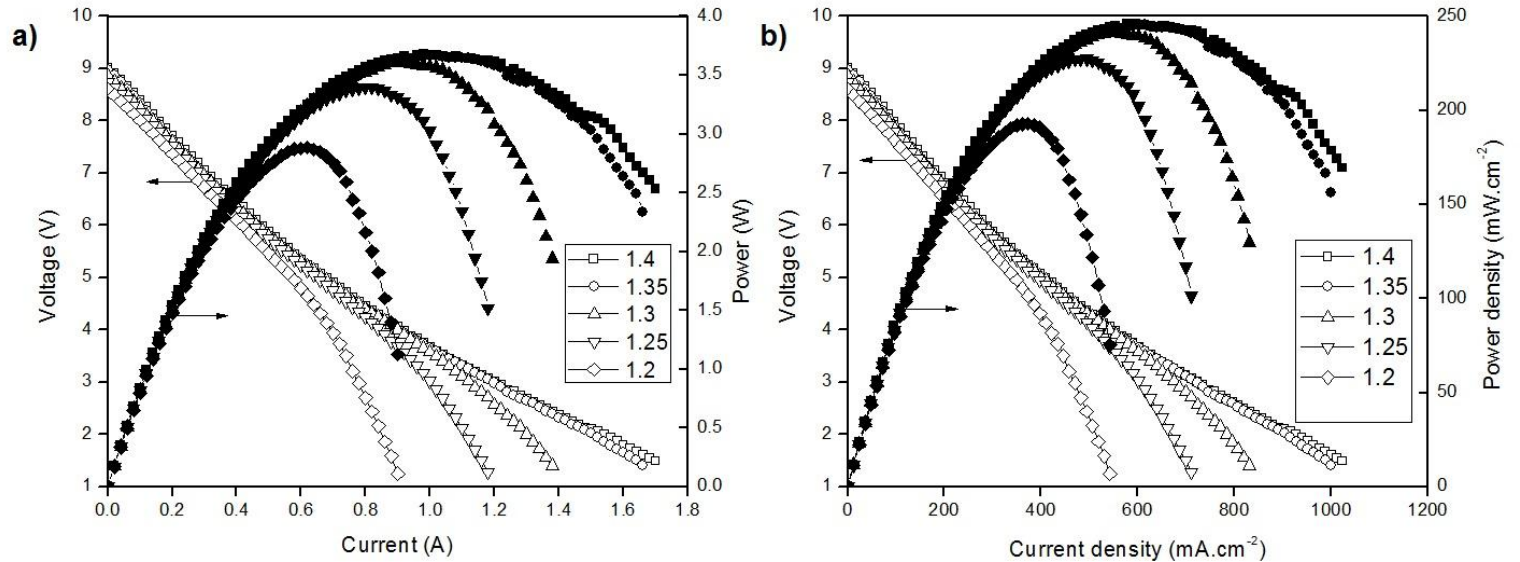

Figure 3: Second $9 \mathrm{mT}-\mathrm{FFC}$ stack operating at $790^{\circ} \mathrm{C}$ in model methane combustion exhaust at equivalence ratios from 1.2 to 1.4 with Table 2 flow rates; a) the total power and current and b) the power density and current density. 
Table 3: Current mT-FFC stack performance comparison with other mT-SOFC stack and single cell results.

\begin{tabular}{cccccc}
\hline Anode/electrolyte/cathode & Fuel & $\begin{array}{c}\text { Temp. } \\
\left({ }^{\circ} \mathrm{C}\right)\end{array}$ & $\begin{array}{c}\text { Single cell } \\
\text { voltage } \\
(\mathrm{V})\end{array}$ & $\begin{array}{c}\text { Power } \\
\text { density } \\
\left(\mathrm{W} \mathrm{cm}^{-2}\right)\end{array}$ & Ref. \\
\hline Ni-YSZ/YSZ/LSM & $\mathrm{H}_{2}$ & 850 & 0.5 & 0.060 & {$[26]$} \\
Ni-YSZ/YSZ/LSM+YSZ,LSM,LSCF & $\mathrm{H}_{2}$ & 750 & 0.7 & 0.380 & {$[31]$} \\
Ni-YSZ/YSZ/LSM & $\mathrm{H}_{2}$ & 750 & 0.5 & 0.385 & {$[35]$} \\
Ni-YSZ/YSZ/LSM & $\mathrm{CH}_{4}$ & 750 & 0.5 & 0.293 & {$[35]$} \\
Ni-YSZ/YSZ/LSM+YSZ,LSM,LSCF & $\mathrm{H}_{2}$ & 750 & 0.5 & $\sim 0.171$ & {$[36]$} \\
Ni-YSZ/YSZ/LSM+YSZ & $\mathrm{H}_{2}$ & 790 & 0.5 & 0.332 & $\begin{array}{c}\text { current } \\
\text { study } \\
\text { Ni-YSZ/YSZ/LSM+YSZ }\end{array}$ \\
& $\begin{array}{c}\text { combustion } \\
\text { exhaust }\end{array}$ & 790 & 0.5 & 0.237 & $\begin{array}{c}\text { current } \\
\text { study }\end{array}$ \\
\hline
\end{tabular}

Electrochemical Impedance Spectroscopy (EIS) was conducted of 2 cells (total cell area $3.34 \mathrm{~cm}^{2}$ ) in series from the mT-FFC stack under the same flow rates given in Table $\mathbf{1}$ and at a temperature of $790^{\circ} \mathrm{C}$. Equipment limitations prevented testing of the entire stack. Fig. $4 \mathbf{a}$ shows the results of the EIS at combustion equivalence ratios of 1.2, 1.25, 1.3, 1.35 and 1.4. Fig. 4c shows the ohmic, polarization and total resistance separately. Both the ohmic and the polarization resistance increase as the combustion equivalence ratio decreases under the conditions given in Table 1. Increasing polarization losses are attributed to the decreasing concentrations of $\mathrm{H}_{2}$ and $\mathrm{CO}$ in the combustion exhaust as the equivalence ratio decreases. Both $\mathrm{H}_{2}$ and $\mathrm{CO}$ participate directly in electrochemical energy conversion according to the following reactions at the anode.

$$
\begin{aligned}
& \mathrm{H}_{2}+\mathrm{O}^{2-} \rightarrow \mathrm{H}_{2} \mathrm{O}+2 e^{-} \\
& \mathrm{CO}+\mathrm{O}^{2-} \rightarrow \mathrm{CO}_{2}+2 e^{-}
\end{aligned}
$$

Lower combustion equivalence ratios have higher concentrations of $\mathrm{N}_{2}$ and $\mathrm{CO}_{2}$, which do not participate directly in the electrochemical reactions and only serve to dilute the fuel 
available. As a result of decreased $\mathrm{H}_{2}$ and $\mathrm{CO}$ in the exhaust at lower equivalence ratios, the gas diffusion and charge transfer losses can increase because less fuel is available. A significant difference is noted in the impedance at low frequencies in the Bode plot (Fig. 4a), which is attributable to diffusion processes in the anode [41]. This results in higher total resistance as the combustion equivalence ratio decreases. As demonstrated, operating at higher equivalence ratios is clearly advantageous to increase the $\mathrm{H}_{2}$ and $\mathrm{CO}$ concentration and peak power density while also decreasing the polarization resistance. However, the highest equivalence ratio that can be achieved in a non-catalytic combustor is limited by the upper flammability limit of the fuel $[42,43]$. 

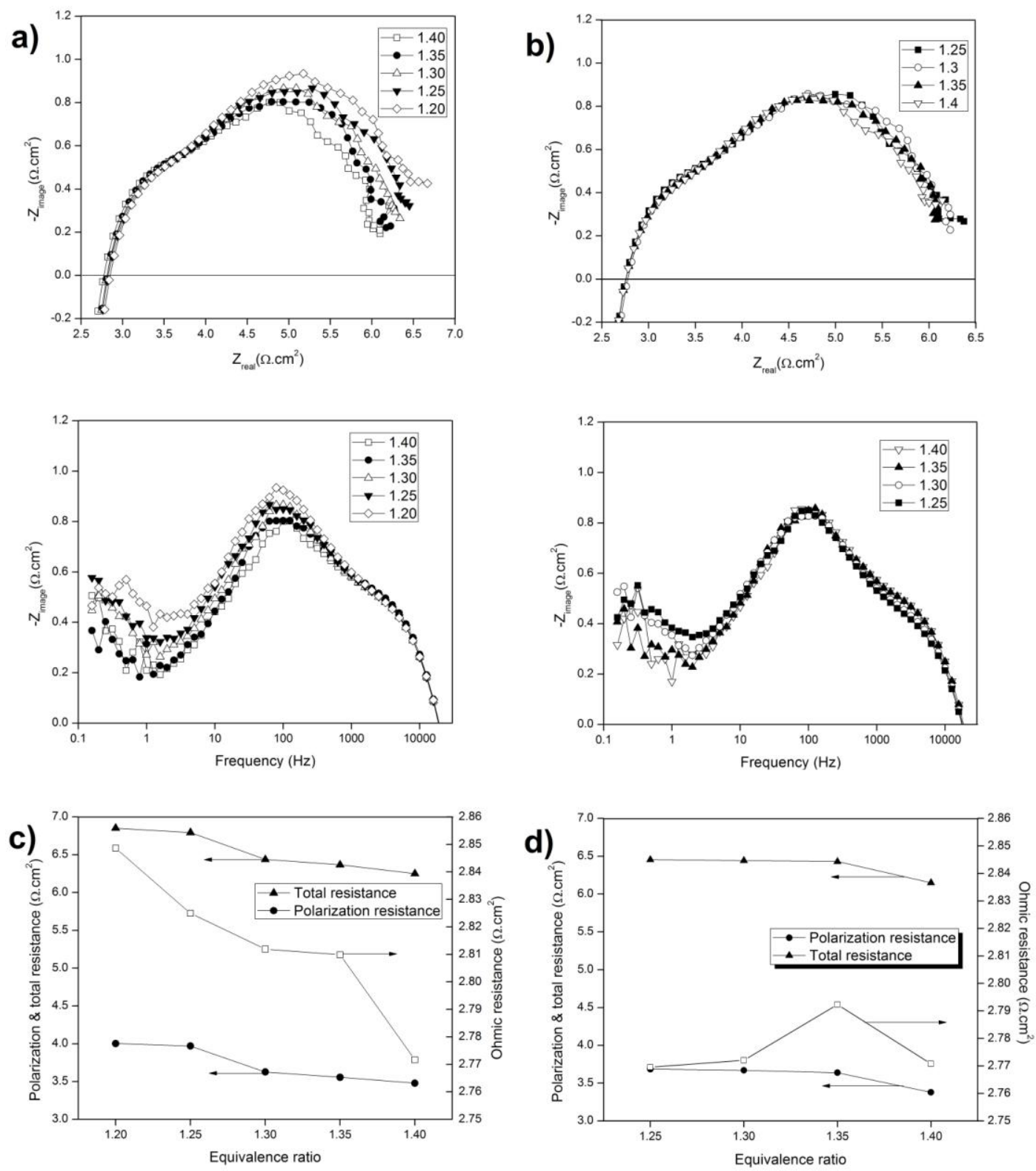

Figure 4: a), c) EIS for $2 \mathrm{mT}-\mathrm{FFCs}$ in series operating at $790^{\circ} \mathrm{C}$ in model methane combustion exhaust at equivalence ratios from 1.2 to 1.4 with Table 1 flow rates. b), d) EIS for the same 2 mT-FFCs in series operating at $790^{\circ} \mathrm{C}$ in model methane combustion exhaust at equivalence ratios from 1.25 to 1.4 with Table 2 flow rates.

Understanding the reason for the increase in ohmic losses with decreasing equivalence ratio is more difficult as the total flow rate of the combustion exhaust changes with equivalence 
ratio. For example, the total flow rate of model combustion exhaust into the stack is $2,224 \mathrm{~mL}$ $\min ^{-1}$ at an equivalence ratio of 1.2 while it is only $1,942.6 \mathrm{~mL} \mathrm{~min}^{-1}$ at an equivalence ratio of 1.4. Each of the exhaust species is preheated in the furnace prior to entering the mT-SOFC stack. However, as the total flow rate of the exhaust varies for each equivalence ratio in Table $\mathbf{1}$, the temperature of the exhaust composition will also vary slightly. These temperature effects may also impact the fuel cell performance and polarization at different equivalence ratios. The higher flow rates, which occur at low equivalence ratios in this case, would favor lower exhaust temperatures in this experimental setup, lower internal fuel cell temperatures and higher ohmic resistance. These effects appear to influence the EIS data observed in Fig. 4c and is confirmed by the Bode plot in Fig. 4a which shows a difference in impedance at high frequency $(\sim 100 \mathrm{~Hz})$ and is attributable to changes in the cathode activation polarization with temperature variation [41].

To examine temperature effects, Fig. $\mathbf{4 b}$ and $\mathbf{4 d}$ show the EIS data for the same 2 cells when the total exhaust flow rate was fixed for all equivalence ratios (Table 2). EIS at an equivalence ratio of 1.2 was not included to make the plots clearer as the data is of comparable magnitude. In this case, the total flow rate of exhaust is fixed, limiting temperature effects on EIS data. The ohmic losses did not show a clear trend and were all within $0.5 \%$ of the average value, indicating that the differences where only measurement error and were not due to differences in the exhaust compositions. Polarization losses did show a clear increasing trend with decreasing equivalence ratio. While the polarization losses were all relatively close, the difference between the polarization and the average polarization was between 1.3 and $6.3 \%$ and do not appear to result from measurement error alone. These results indicate that the polarization losses do vary with equivalence ratio of the fuel-rich combustion while the ohmic losses have little to no variation with the exhaust species. Temperature effects are clearly important as lower 
flow rates achieved higher model exhaust temperatures and result in higher power density and lower ohmic and polarization resistance in this setup.

\section{CONCLUSIONS}

A 9 mT-FFC stack was constructed and tested in model combustion exhaust from fuel-air equivalence ratios of 1.2 to 1.4 . The stack showed significant performance in the model combustion exhaust achieving a peak power density of $246 \mathrm{~mW} \mathrm{~cm}{ }^{-2}$ having a stack active area of $15.03 \mathrm{~cm}^{2}$. Performance and EIS were conducted on the stack for two different FFC based micro-CHP conditions. The first represents a FFC micro-CHP system with a fixed, first stage combustion, fuel flow rate to the burner, fixed stack geometry and varying oxidant flow rate. The second scenario represents a fixed total exhaust flow rate with both of the first stage combustion fuel and oxidant flow rates varying. EIS results indicate that ohmic losses of the fuel cell do not vary with the exhaust composition while the polarization losses increase with decreasing concentration of $\mathrm{H}_{2}$ and $\mathrm{CO}$ in the exhaust. Performance results obtained indicate that mT-FFC based micro-CHP has potential for significant power generation and a potentially simplified system configuration. Future work should include long-term performance testing as the disproportionation of $\mathrm{CO}$ can deposit carbon on the anode through the inverse Boudouard reaction.

\section{ACKNOWLEDGEMENT}

This material is supported under prime award number DE-EE0006031 from the US Department of Energy and matching funding under award number 53367 from the New York State Energy Research and Development Authority (NYSERDA) and under NYSERDA contract 61736. This material is also based upon work supported by the National Science Foundation Graduate Research Fellowship Program under Grant No. 1247399. 


\section{REFERENCES}

[1] A. Adam, E.S. Fraga, D.J.L. Brett, Options for residential building services design using fuel cell based micro-CHP and the potential for heat integration, Appl. Energy 138 (2015) 685-694. [2] R.J. Gorte, Recent developments towards commercialization of solid oxide fuel cells. AIChE Journal 51 (2005) 2377-2381.

[3] C. Song, Fuel processing for low-temperature and high-temperature fuel cells: challenges, and opportunities for sustainable development in the 21st century, Catal. Today 77 (2002) 17-49. [4] P.E. Santangelo, P. Tartarini, Fuel cell systems and traditional technologies. Part I: experimental CHP approach, Applied Thermal Engineering 27 (2007) 1278-1284.

[5] A.D. Peacock, M. Newborough, Impact of micro-CHP systems on domestic sector $\mathrm{CO}_{2}$ emissions, Applied Thermal Engineering 25 (2005) 2653-2676.

[6] P. Kazempoor, V. Dorer, F. Ommi, Evaluation of hydrogen and methane-fueled solid oxide fuel cell systems for residential applications: Systems design alternative and parameter study, Int. J. Hydrogen Energy 34 (2009) 8630-8644.

[7] H. Xu, Z. Dang, B. Bo-Feng, Analysis of a $1 \mathrm{~kW}$ residential combined heating and power system based on solid oxide fuel cell, Applied Thermal Engineering 50 (2013) 1101-1110. [8] P. Lisbona, A. Corradetti, R. Bove, P. Lunghi, Analysis of a solid oxide fuel cell system for combined heat and power applications under non-nominal conditions, Electrochimica Acta 53 (2007) 1920-1930.

[9] F. Zink, Y. Lu, L. Schaefer, A solid oxide fuel cell system for buildings, Energy Conversion and Management 48 (2007) 809-818.

[10] M. Horiuchi, S. Suganuma, M. Watanabe, Electrochemical power generation directly from combustion flame of gases, liquids, and solids, J. Electrochem. Soc. 151 (2004) A1402-A1405. 
[11] M. Horiuchi, S. Suganuma, M. Watanabe, Y. Tokutake, M. Mogensen, P. of the $6^{\text {th }}$ European solid oxide fuel cell forum 6 (2004) 154-162.

[12] K. Wang, R.J. Milcarek, P. Zeng, J. Ahn, Flame-assisted fuel cells running methane, Int. J. Hydrogen Energy 40 (2015) 4659-4665.

[13] K. Wang, P. Zeng, J. Ahn, High performance direct flame fuel cell using a propane flame, P. Combust. Inst. 32 (2011) 3431-3437.

[14] X. Zhu, B. Wei, Z. Lü, L. Yang, X. Huang, Y. Zhang, M. Liu, A direct flame solid oxide fuel cell for potential combined heat and power generation, Int. J. Hydrogen Energy 37 (2012) $8621-8629$.

[15] H. Kronemayer et al., A direct-flame solid oxide fuel cell (DFFC) operated on methane, propane, and butane, J. Power Sources 166 (2007) 120-126.

[16] Y. Wang et al., Experimental characterization of a direct methane flame solid oxide fuel cell power generation unit, J. Electrochem. Soc. 161 (2014) F1348-F1353.

[17] K. Wang et al., A high-performance no-chamber fuel cell operated on ethanol flame, J. Power Sources 177 (2008) 33-39.

[18] Y.Q. Wang, Y.X. Shi, X.K. Yu, N.S. Cai, S.Q. Li, Integration of solid oxide fuel cells with multi-element diffusion flame burners, J. Electochem. Soc. 160 (2013) F1241-F1244.

[19] M. Horiuchi et al., Performance of a solid oxide fuel cell couple operated via in situ catalytic partial oxidation of n-butane, J. Power Sources 189 (2009) 950-957.

[20] W. Yu-guang et al., The study of portable direct-flame solid oxide fuel cell (DF-SOFC) stack with butane fuel, J. Fuel Chem. Technol. 42 (2014) 1135-1139. [21] Y. Wang, Y. Shi, X. Yu, N. Cai, Thermal shock resistance and failure probability analysis on solid oxide electrolyte direct flame fuel cells, J. Power Sources 255 (2014) 377-386. 
[22] Y. Wang, Y. Shi, M. Ni, N. Cai, A micro tri-generation system based on direct flame fuel cells for residential applications, Int. J. Hydrogen Energy 39 (2014) 5996-6005.

[23] M. Vogler, M. Horiuchi, W.G. Bessler, Modeling, simulation and optimization of a nochamber solid oxide fuel cell operated with a flat-flame burner, J. Power Sources 195 (2010) 7067-7077.

[24] R.J. Milcarek, K. Wang, R.L. Falkenstein-Smith, J. Ahn, Micro-tubular flame-assisted fuel cells for micro-combined heat and power systems, J. Power Sources 306 (2016) 148-151. [25] R.J. Milcarek, M.J. Garrett, A. Baskaran, J. Ahn, Combustion Characterization and Model Fuel Development for Micro-tubular Flame-assisted Fuel Cells, J. Vis. Exp. (), e54638, doi:10.3791/54638 (2016), in-press.

[26] W.S. Hsieh, P. Lin, S.F. Wang, Fabrication of electrolyte supported micro-tubular SOFCs using extrusion and dip-coating, Int. J. Hydrogen Energy 38 (2013) 2859-2867.

[27] N.M. Sammes, Y. Du, R. Bove, Design and fabrication of a $100 \mathrm{~W}$ anode supported microtubular SOFC stack, J. Power Sources 145 (2005) 428-434.

[28] H. Sumi, T. Yamaguchi, K. Hamamoto, T. Suzuki, Y. Fujishiro, Electrochemical analysis for anode-supported microtubular solid oxide fuel cells in partial reducing and oxidizing conditions, Solid State Ionics 262 (2014) 407-410.

[29] K. Kendall, M. Palin, A small solid oxide fuel cell demonstrator for microelectronic applications, J. Power Sources 71 (1998) 268-270.

[30] F. Calise, G. Restuccia, N. Sammes, Experimental analysis of micro-tubular solid oxide fuel cell fed by hydrogen, J. Power Sources 195 (2010) 1163-1170.

[31] K. Kendall, Progress in Microtubular Solid Oxide Fuel Cells, Int. J. Appl. Ceram. Technol. 7 (1) (2010) 1-9. 
[32] S.-B. Lee, T.-H. Lim, R.-H. Song, D.-R. Shin, S.-K. Dong, Development of a 700 W anodesupported micro-tubular SOFC stack for APU applications, Int. J. Hydrogen Energy 33 (2008) 2330-2336.

[33] K.S. Howe, G.J. Thompson, K. Kendall, Micro-tubular solid oxide fuel cells and stacks, J. Power Sources 196 (2011) 1677-1686.

[34] H. Monzón, M.A. Laguna-Bercero, A. Larrea, B.I. Arias, A. Várez, B. Levenfeld, Design of industrial scalable microtubular solid oxide fuel cells based on an extruded support, Int. J. Hydrogen Energy 39 (2014) 5470-5476.

[35] W.-S. Hsieh, P. Lin, S.-F. Wang, Fabrication of electrolyte supported micro-tubular SOFCs using extrusion and dip-coating, Int. J. Hydrogen Energy 38 (2013) 2859-2867.

[36] N. Akhtar, S. Decent, D. Loghin, K. Kendall, Mixed-reactant, micro-tubular solid oxide fuel cells: An experimental study, J. Power Sources 193 (2009) 39-48.

[37] T.-H. Lim, J.-L. Park, S.-B. Lee, S.-J. Park, R.-H. Song, D.-R. Shin, Fabrication and operation of a $1 \mathrm{~kW}$ class anode-supported flat tubular SOFC stack, Int. J. Hydrogen Energy 35 (2010) 9687-9692.

[38] Y.-W. Sin, K. Galloway, B. Roy, N.M. Sammes, J.-H. Song, T. Suzuki, M. Awano, The properties and performance of micro-tubular (less than $2.0 \mathrm{~mm}$ O.D.) anode supported solid oxide fuel cell (SOFC), Int. J. Hydrogen Energy 36 (2011) 1882-1889.

[39] L. Sun, Y. Hao, C. Zhang, R. Ran, Z. Shao, Coking-free direct-methanol-flame fuel cell with traditional nickel-cermet anode, Int. J. Hydrogen Energy 35 (2010) 7971-7981. [40] R.J. Milcarek, M.J. Garrett, K. Wang, J. Ahn, Micro-Tubular Flame-assisted Fuel Cells Running Methane, Int. J. Hydrogen Energy, in-press. 
[41] Y.D. Hsieh, Y.H. Chan, S.S. Shy, Effects of pressurization and temperature on power generating characteristics and impedances of anode-supported and electrolyte-supported planar solid oxide fuel cells, J. Power Sources 299 (2015) 1-10.

[42] S.R. Turns, An Introduction to Combustion: Concepts and Applications, second ed., McGraw-Hill, New York, 2000.

[43] I. Glassman, R.A. Yetter, N.G. Glumac, Combustion, fourth ed., Academic Press, Waltham, MA, 2015. 